\title{
The hormonal regulation of blood respiratory function in cattle during the neonatal period
}

\author{
V Snitynsky, H Antonyak \\ Institute for Research in Animal Physiology and Biochemistry UAAS, 290034 Lviv, Ukraine
}

The changes of oxygen transport rate caused by alterations of hemoglobin properties in newborn animals are considered to provide their survival and adaptation to postnatal life. Functional activity of hemoglobin is known to be conditioned by red cell metabolism level, namely by intensity of formation of 2,3 diphosphoglycerate (2,3-DPG) - modulator of proteins affinity to oxygen. Blood respiratory function was shown to depend on the influence of thyroid hormones, but the age peculiarities of thyroxin regulatory action on functional characteristics of cattle erythrocytes during the neonatal period of ontogenesis have not been studied. In this connection we have investigated the relations between plasma thyroxin levels and red cell metabolism intensity in newborn, 1-, 10- and 30-day calves. For comparison we have studied the erythrocyte metabolism indices in adult animal.

Blood samples were obtained by jugular vein puncture from 10 calves at birth and in 1-, 10- ,30-day intervals as well as from 10 adults. Washed erythrocytes were depleted of white cells and platelets by chromatography on mixed $\alpha$-cellulose and microcrystalline cellulose columns.

2,3-DPG in red cells were determined enzymatically in neutralized perchloric acid extracts according to Ericson and De Verdier (1972). Enzyme activities in hemolysates were determined at $37^{\circ} \mathrm{C}$, pH 8.0 as described by Beutler (1975) and expressed as $\mu$ moles substrate converted per 1 minute (IU) in relation to the concentration of hemoglobin $(\mathrm{Hb})$ in the sample. Plasma thyroxin level was evaluated by means of radioimmunological assay. All data were analyzed using the Student t-test.

We have established that plasma thyroxin concentration being low enough at birth increased at the first day of postnatal life and remained on the high level in ten-day old animals. This was accompanied by intensive production of 2,3-DPG in erythrocytes of calves during the period of 10 days after birth. Then concentration of this compound decreased rapidly and approached the adult levels after about 1 month of life. It has been shown that thyroid hormones enter the erythrocyte and reveal their modulatory effect on 2,3-DPG level by means of their influence on the activity of Rapoport - Leubering enzyme - diphosphoglycerate mutase (DPGM). Other glycolytic enzymes, notably hexokinase (HK) and pyruvate kinase (PK), which are thought to influence the 2,3-DPG pool indirectly through their effects upon the rate of glycolysis, are also susceptible to the thyroxin action. According to our data the postnatal activation of DPGM and $\mathrm{HK}$ in erythrocytes occurred simultaneously with 2,3-DPG concentration increase. While PK activity level progressively decreased as newborns aged which greatly contributed to 2,3-DPG accumulation.

These findings suggest the regulatory action of thyroid hormone on red cell metabolism and provide the evidence, that increased formation of thyroxin in calves in the period of neonate promotes the alternations in erythrocyte metabolic processes directed on the 2,3-DPG elevation. Despite 2,3-DPG has little modulatory effect on $\mathrm{Hb}$ function and reveals its action on $\mathrm{Hb}$ saturation mainly through the influence on intracellular $\mathrm{pH}$ and the Bohr effect, we consider that postnatal increase of 2,3-DPG is one of the main causes of rapid decrease of blood oxygen delivery in animal tissues and may represent an important factor which provokes the intensification of oxidative processes in the cells.

\begin{tabular}{|c|c|c|c|c|c|}
\hline $\begin{array}{l}\text { Investigated stage } \\
\text { of development }\end{array}$ & $\begin{array}{l}\text { Thyroxin } \\
\text { nmoles/l }\end{array}$ & $\begin{array}{c}\text { 2,3-DPG } \\
\mu \text { moles/g Hb }\end{array}$ & $\begin{array}{l}\text { DPGM } \\
\mathrm{IU} / \mathrm{g} \mathrm{Hb}\end{array}$ & $\begin{array}{c}\mathrm{HK} \\
\mathrm{IU} / \mathrm{g} \mathrm{Hb}\end{array}$ & $\begin{array}{c}P K \\
\mathrm{IU} / \mathrm{g} \mathrm{Hb}\end{array}$ \\
\hline $\begin{array}{l}\text { At birth } \\
\text { Days after birth }\end{array}$ & 32.9 & 1.56 & 12.7 & 0.40 & 9.53 \\
\hline 1 & 56.7 & 4.23 & 15.5 & 0.55 & 7.40 \\
\hline 10 & 57.4 & 8.40 & 15.8 & 0.62 & 5.88 \\
\hline 30 & 50.8 & 2.67 & 11.5 & 0.45 & 4.82 \\
\hline Adults & - & 2.25 & 8.2 & 0.48 & 4.05 \\
\hline
\end{tabular}

